\title{
Factors Affecting Demand Planning in the South African Clothing Industry
}

\author{
NJ Matsoma, IM Ambe \\ School of Public and Operations Management, University of South Africa \\ matsonj@unisa.ac.za, ambeim@unisa.ac.za
}

\begin{abstract}
The decline in the number of clothing manufacturers and the effect of globalisation have contributed to complexities in estimations and the scheduling of demand, as well as lead time management in the South African clothing industry. This article explores demand planning factors affecting the South African clothing industry, with specific reference to Gauteng. The study was necessitated due to demand planning challenges facing the South African clothing industry as well as economic factors which contribute to inaccuracies in clothing demand planning. The study makes an impact in the garment production factories of Gauteng in South Africa and adds to the philosophy of demand planning practices. It uncovers key factors affecting demand planning practices in the Gauteng clothing industry, South Africa. The study is explorative and descriptive in nature and it uses SPSS to analyse data. The findings revealed that there were factors affecting how demand planning practices were conducted in the clothing industry. The factors that have a significant influence on clothing demand planning include the scheduling of the manufacturing of customers' orders, planning for fashion clothes, the use of the POS system, clothing imports, estimating future clothing requirements, recession and the effect of the late arrival of clothes. Therefore, clothing industry stakeholders should take these factors into consideration when planning for their demand to ensure customer needs can be fully met, thus improving the performance of the clothing industry.
\end{abstract}

Keywords: Demand planning, demand planning approaches, manufacturer, fabric suppliers, fashion designers, clothing industry, Gauteng, South Africa

\section{Introduction}

Since 2004, when the South African government lowered tax duties which are paid when goods/services are imported into the country, the South African clothing industry has been declining (Nattrass \& Seekings, 2012:10). This decline had a negative effect on the level of sales, employment, gross domestic product (GDP), as well as on the accuracy of demand planning (Kim, 2012:1285; Rotunno, Vèzina \& Wang, 2013:2). In SA the fashion industry is one of the fifth major employment segments in the country. The SA clothing industry also makes a significant contribution to the country's growth in terms of sales (Gauteng Growth and Development Agency (GGDA), 2014). Hence, demand planning is critical in the SA clothing industry. Demand planning is critical in the clothing industry. Globally, the clothing industry is associated with a minimum period of garment existence, unstable customer needs and a variety of fashion styles with extensive lead times (Wong \& Guo, 2010:614). According to Jonson and Tolstoy (2012:62), proper application of demand planning activities is required for organisations to achieve a competitive advantage. Demand planning, however, is subject to discrepancies and complexities, and this is one of the greatest challenges faced by the SA clothing industry (Aksoy et al., 2012:222; Bhardwaj \& Fairhurst, 2010:165). The decline in the figure of garment production factories in the country and the effect of globalisation have contributed to complexities in estimations, scheduling, as well as lead time management (Sekerden, 2011:7). In addition, the influx of Chinese products into the country has affected the accuracy of demand planning in the clothing industry of the country (Rotunno et al., 2013:2).

The clothing industry has also experienced a reduction in the quantity of clothing organisations, a reduction in manufacturing output figure as well as fluctuating employment as reflected in section 1.2.3 (GGDA, 2014:3; IQ Business, 2014:3; Nattrass \& Seekings, 2012:2). Numerous studies have been conducted on demand planning in the clothing industry. Authors such as Priest (2005), Sen (2008), Wark (2006) and Steytler and Powell (2010:6) explored selected components of demand planning such as fashion, clothing estimations and recession. In South Africa, authors such as Volk (2006), Nattrass and Seekings (2012) and Oberhofer (2012) 
also explored various components of the SA clothing industry, such as clothing imports, wage setting implications and fashion designing. However, these studies investigated selected components or elements of demand planning in the clothing industry. Hence, there is a gap and a need for an empirical investigation through a comprehensive study on factors affecting demand planning in the clothing industry. Given the importance of demand planning to the competitive performance of the clothing industry, the study explored demand planning in the SA clothing industry with specific reference to Gauteng, based on a cross-section study.

This article therefore explores factors affecting demand planning in the clothing industry in Gauteng, South Africa. The article makes a contribution to the improvement of demand planning, not only to the Gauteng clothing industry but to the South African industry at large. Through the application of proper demand planning practices, customer needs can be fully met, thus improving the performance of the clothing industry. The remaining parts of this article discuss the literature review, research design and methodology, the findings and conclusion.

\section{Literature Review}

This section of the article presents a review of demand planning practices in the South African context. The section concludes with a review of the factors affecting demand planning.

Demand planning in perspective: Demand planning is critical to the success of organisations (Rexhausen, Pibernick \& Kaiser, 2012:269). In the 1980s, organisations were relying on their own decisions when they planned for customer demands. However, with the changing business conditions, organisations have become flexible in demand planning (Bhardwaj \& Fairhurst, 2010:165; Pretorius, 2013:1). Proper demand planning exists when organisations are able to succeed in obtaining correct items, at reasonable costs and at the correct time (Mason-Jones, Naylor \& Towill, 2000:4061). The implementation of demand planning is affected by factors such as huge market demand for certain products, demand location, supplier distance, product variety, different data technology systems, matching demand and supply, as well as bulk product ordering that has a significant effect on planning (De Villiers, Nieman \& Niemann, 2011). In the midst of all these factors organisations, including the clothing industry, have to prevent errors when planning for customer needs (Gauteng Growth and Development Agency (GGDA), 2014; Nattrass \& Seekings, 2012; Oberhofer, 2012; Volk, 2006). Demand planning creates product value for customers by providing products according to customer needs and preferences (Priem and Swink, 2012:48).

Demand planning in the clothing industry: Demand planning is critical in the South African (SA) clothing industry. Chaudhary (2011:2) asserts that clothes are one of the basic requirements of human beings and that the demand will continue to exist. The demand planning process for customer clothing starts at the producers of raw materials and continue to fabric suppliers, clothing manufacturers and finally to the end customer (Oberhofer, 2012:66; Nattrass \& Seekings, 2012:17; GGDA, 2014:2) The demand planning process of the clothing industry indicates how material production supply is communicated within the supply chain (SC) partners (Larsson, Peterson \& Mattila, 2012:72). Surchi (2011:258) affirms that communication is crucial for proper demand planning in the clothing industry. Therefore, clothing manufacturers and retailers are required to work together in order to meet customer demand (Castelli \& Brun, 2010:26; Nenni, Guistiniano \& Pirolo, 2013:4). The clothing industry is multifaceted and there are several manufacturing lines involved in each stage of the production process (Nattrass \& Seekings, 2012:17). Also, the types of customers involved complicate the demand planning process (Aksoy, Azturk \& Sucky, 2012:222). Thomassey (2010:471) indicated that the demands of fashion customers differ from the demand for basic clothes. Hence, there are discrepancies and complexities in demand planning for clothing. Gereffi and Frederick (2010:17) mentioned that the complexity of clothing production is increasing as garments are produced. This on its own poses a challenge for demand planning in the clothing industry, including the SA clothing industry. Therefore, demand planning remains a major issue for the SA clothing industry.

Review of the South African clothing industry: The SA clothing industry has existed since the Second World War (Salm, 2002:7). The production operation in this sector requires more physical work and it employs people who are less educated and less skilled (Nordås, 2004). The clothing industry is often seen as a 
low income payer with fewer possibilities for research innovations and it is associated with strong workforce legislations (Nattrass \& Seekings, 2012:8). According to Vlok (2006:227), the industry remains a critical division with regards to employment development. Having realised the importance of demand planning, in 1994 the city of Johannesburg established centres where various clothing styles are produced with the aim of improving clothing demand (Oberhofer, 2012:7). The SA clothing industry consists of three key stakeholders, namely fabric suppliers, fashion designers and clothing manufacturers (GGDA, 2014:2; Oberhofer, 2012:65; Staritz \& Morris, 2013:9). It is critical to note that, in the process of satisfying customers' clothing demands, the SA clothing industry is faced with opportunities as well as challenges (Nattrass \& Seekings, 2012:6). Due to the lack of proper demand planning, there are inconsistencies that have affected the industry in the following ways:

- Changes in the number of clothing production organisations in South Africa: There have been changing: trends in the number of clothing organisations in South Africa over the years. In 1998, there were 784 clothing manufacturers. By 2000, there was a decline to 672, while there was an increase to 1008 clothing production organisations in 2006 (GGDA, 2014:3). These trends may have emanated from the effect of inconsistencies in demand planning, as well as other factors, such as clothing imports and the recession (Gereffi \& Lee, 2012:28; Steytler \& Powell, 2010:2). This clearly indicates that there are changing trends in the number of clothing production organisations in South Africa.

- Decline in manufacturing output: The clothing industry makes a significant contribution to the manufacturing sector of a country. In 2005, the clothing industry in SA grew by over R12 500 million and then there was a sharp decline to less than R11 500 million in 2006 (IQ Business, 2014:3). From 2007 to 2012, the industry was stable, and in 2013 there was a slight growth to almost R13 500 million (IQ Business, 2014:3). The decline in the contribution of the manufacturing sector in this industry from 2006 to 2012 may be the reason for a decline in employment in the clothing industry (IQ Business, 2014:3).

- Fluctuation in employment: Over the years, the clothing industry has also experienced fluctuations with regard to employment (GGDA, 2014:3). According to Nattrass and Seekings (2012:2), there is evidence of fluctuations in the number of employees within the SA clothing industry. In 1950, the level of employment in the industry was at 50000 workers, in 2005 the employment figure was at 142865 workers, while in 2013, the figure was at 80 000. This decline indicates that the employment level may be the result of material shortages, as well as a rise in the import of clothing from China.

As indicated in the discussion above, the productivity of the SA clothing industry can be affected by changing trends in the number of clothing production organisations, the decline in manufacturing output, as well as fluctuations in employment. This indicates that better approaches are required to improve planning for clothing demands.

Factors affecting demand planning in the clothing industry: There are challenges that have an effect on demand planning in the clothing industry in South Africa. These challenges stem from the incorrect scheduling of clothing material, planning for fashion clothes, incorrect use of the point of sale (POS) system, an influx of clothing imports, incorrect estimations of clothes, the recession as an unfavourable economic condition, and the late arrival of clothing material (Aksoy et al., 2012:223; Nattrass \& Seekings, 2012:17). These challenges have an effect on demand planning in the SA clothing industry. The challenges are briefly explained below.

- Incorrect scheduling of clothing material: The scheduling of clothing material is one of the challenging aspects that affect proper demand planning (Annadurai \& Uthayakumar, 2010:3465). Scheduling is defined as the utilisation of correct and timely resources in manufacturing, fabric acquisition and production capabilities (Maravelias, 2012:1815). The scheduling of material can become multifaceted in the clothing industry due to the various stages involved in the production process, as well as the variation in clothing and the types of customers involved (Aksoy et al., 2012:222). Gereffi and Frederick (2010:17) mentioned that in South Africa, the complexity of clothing production is increasing as garments produced require more detailed trimming, especially with fashion clothing.

- Planning for fashion clothes: The fashion industry is a fast-moving industry with customers who are fashion-driven and who are not willing to compromise for the styles they demand (Wang, Gou, Sun \& Yue, 2012:462). Customers' hesitation regarding fashion clothes has increased (Shen, Choi, Wang \& Lo, 2013:266). This causes demand planning and prediction regarding fashion to become challenging. According to Wang et al. (2012:462), fashion clothes last for a short period. Bhardwaj and Fairhurst 
(2010:166) confirmed that fashion clothes change constantly and require constant follow-ups. Hence, demand planning in the SA clothing industry becomes difficult. Alack of skills to analyse fashion trends is also a challenge, which affects demand planning in the Gauteng clothing industry. Barnes and LeaGreenwood (2010:762) argued that fashion customers consult garment style magazines and watch garment style shows on television and search for new fashion designs when shopping for clothes. Hence, it becomes challenging to implement demand planning for fashion clothes with accuracy.

- Incorrect use of the point of sale (POS) system: POS is an automated system used by retail outlets to process the sale of items bought by customers (Karnin \& Walach, 2015:1). According to Folk, Bohen, Sanders and Johnson (2011:5), the POS system reflects the history of sold inventories. This service technology, called the POS system, also assists SA clothing manufacturers to obtain sales data from retail clothing stores. This prevents human errors from happening when manual sales are recorded in retail stores (Pretorius, 2013:1). Hamister (2011:432) said that information distortion is a challenge when using the POS system. According to Chaudhry and Hodge (2012:70), it is questionable whether the POS systems of clothing retailers are linked to the demand planning system of clothing manufacturers. When the clothing industry's system is not linked to the customers' systems, errors are bound to occur in demand planning (Ni \& Fan, 2011:1531).

- Influx of clothing imports: The influx of imports has reduced employment globally, as well as in South Africa (Ramdass, 2007:1). Imports are the merchandise or goods that enter a country (Ramdass, 2007:4). Laudal (2010:72) alluded that imports emanate from international trade, which is now affecting the economy of growing countries. According to GGDA (2014:4), the increase of imports in the Gauteng clothing industry affects the proper implementation of demand planning processes in the industry. This results in discrepancies in demand planning for clothes as additional clothing supplies in the country make it difficult to predict the market for clothes and to deal with competition in the clothing industry.

- Incorrect estimations of clothes: Estimating with accuracy affects the complexity of manufacturing processes (Thomassey, 2010:471; Aksoy et al., 2012:222). In order to know the quantities of clothes that will be required in future, estimations have to be implemented. The correct and accurate estimation of clothing requirements is crucial in the clothing industry. According to Bhardwaj and Fairhurst (2010:169), failure to estimate future clothing styles will affect demand planning as the industry will not be able to attract fashion-sensible customers.

- Recession as an unfavourable economic condition: The 2002 global recession destabilised the performance of the majority of organisations in South Africa (Simos, 2002:32). Sekerden (2011:7) defines a global recession as an international economic downturn. Steytler and Powell (2010:6) mentioned that the SA government suffered financially as a result of the global recession. Manufacturing operations in South Africa were deeply affected as a result of the global recession. In 2008, factories in the SA clothing industry, especially on the north coast of KwaZulu-Natal (KZN), diminished as a result of the international monetary crisisin the United States of America. These factories were exporting their clothing produce to the United States of America (Nattrass \& Seekings, 2012:9).

- Late arrival of clothes: Thelate arrival of clothing material causes delays in the production schedule for clothes (Thomassey, 2010:471). Ordering fabrics from international suppliers might result in the late arrival of fabric and can affect the proper implementation of demand planning in the SA clothing manufacturing industry. Nenni et al. (2013:1) confirmed that it takes time for clothing fabrics to arrive at manufacturing plants. Delays in the arrival of fabric result from supplier distances (Aksoy et al., 2012:223; Thomassey, 2010:471), and this is a challenging issue in the SA clothing industry.

Based on the review above, there are factors that affect demand planning in clothing industries. These factors need to be managed properly to ensure effective and efficient management of demand planning in the clothing industry, especially in South Africa where the industry experiences fluctuations in the number of clothing manufacturers, manufacturing output as well as in employment(GGDA, 2014:3; IQ Business, 2014:3;Nattrass \& Seekings, 2012:2; Volk, 2006:229; Media Club South Africa, 2015).

\section{Research Design and Methodology}

This article explores factors affecting demand planning in the clothing industry in Gauteng, South Africa. An exploratory and descriptive study was conducted. A mixed research approach (qualitative and quantitative) was used. A survey was conducted among clothing industry stakeholders in Gauteng. A survey involves 
obtaining data on situations, occurrences or events (Leedy \& Ormrod, 2014:195).In South Africa, the clothing industries are found in the Western Cape, KwaZulu-Natal, the Free State and Gauteng. Gauteng was chosen because it was convenient and accessible to the researcher. A non-probability sampling technique was used. This means the researcher chose a sample size that was easily available and accessible. Convenient sampling was employed in this study. Population of study constituted 306 key stakeholders in the clothing industry: fabrics suppliers, fashion designers and clothing manufacturers. A total sample of 56 key clothing industries was chosen Managers, supervisors and specialists constituted the sample of the study based on convenience. A semi-structured questionnaire was mailed and hand-delivered to the respondents, who were based in Pretoria and Johannesburg. The questionnaire was measured using a Likert scale format. The structured questions were analysed descriptively using the statistical package for the social sciences (SPSS) and are presented in this article by means of tables and figures.

\section{Results}

This section of the article presents the findings on the factors affecting demand planning in the Gauteng clothing industry. Respondents were asked to indicate their level of agreement on the following factors that affect demand planning in the clothing industry: scheduling, planning for fashion, point of sale (POS) systems, imports of clothes, estimating future clothing requirements, the influence of a recession and the effect of the late arrival of clothes.

Scheduling the manufacturing of customers' orders: Respondents were asked to indicate their level of agreement on fourteen (14) statements relating to scheduling the manufacturing of customers' orders. Figure 1 below shows the percentage of respondents of the clothing industry stakeholders who strongly disagreed or disagreed, who neither agreed nor disagreed and who agreed or strongly agreed with statements regarding the scheduling of the manufacturing of customers' orders. Table 1 presents the description of the statement numbers in Figure 1.

Figure 1: The perception of respondents regarding scheduling the manufacturing of customers' orders (as a \%).

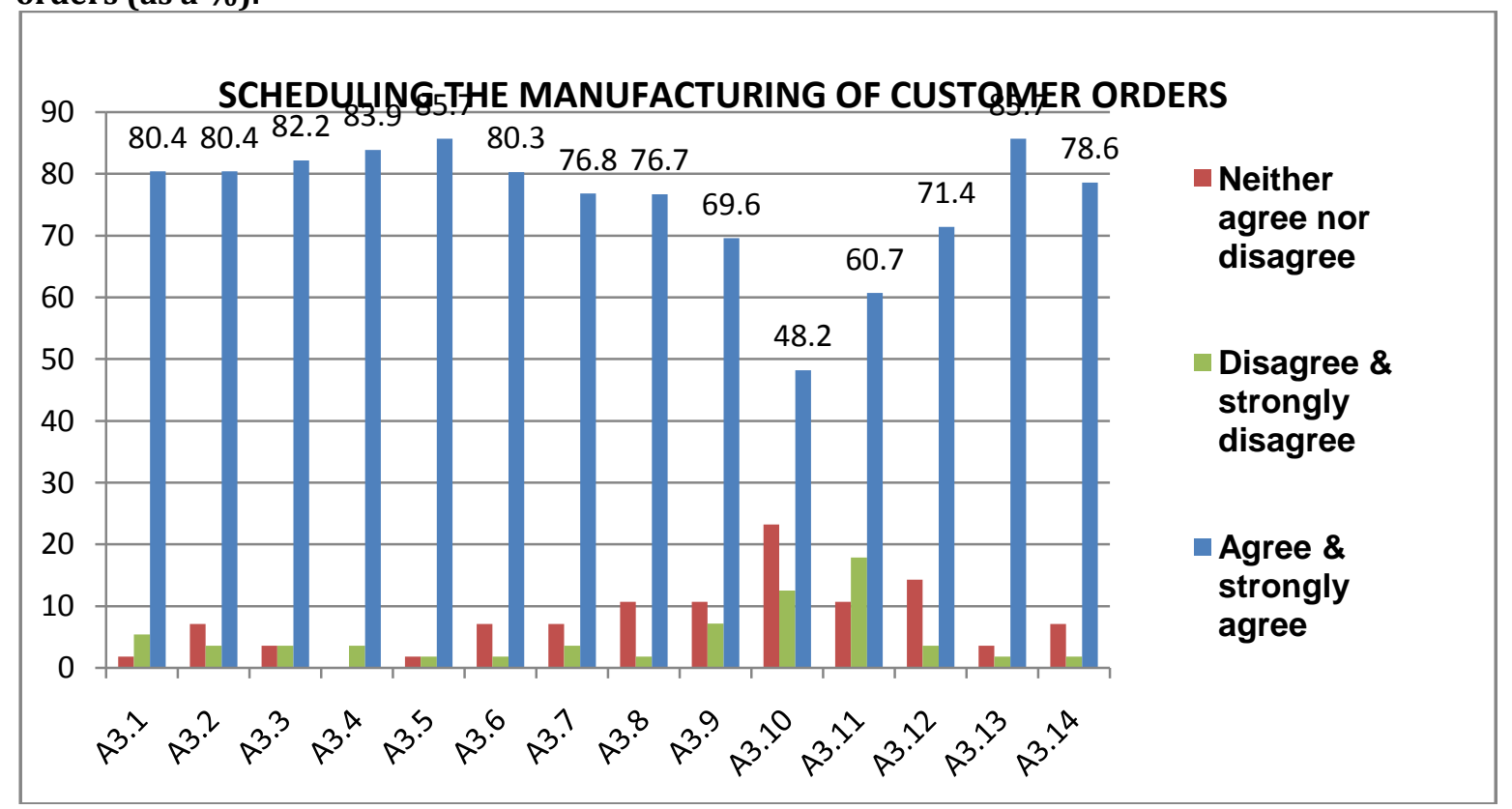

* Note: some of the percentages do not add up to $100 \%$ on account of missing values, because some of the respondents did not answer specific statements relating to factors affecting demand planning.

As is shown in the graph (see Figure 1), a large majority (above 70\%) of the clothing industry stakeholders agreed or strongly agreed with 11 of the 14 procedures that need to be followed when scheduling the 
manufacturing of customers' orders. However, with regard to the statement whether retailers' demands regarding low cost charges on orders should be accommodated, only $48,2 \%$ of the respondents agreed or strongly agreed with the statement, indicating that more than half of the responses were neutral or in disagreement with the statement. In addition, only $60,7 \%$ of the respondents agreed or strongly agreed with the statements about clothing materials or fabrics needed in the manufacturing process that may arrive late, also indicating that a high $40 \%$ of the respondents were neutral or in disagreement with this statement. There was strong agreement $(85,7 \%)$ that communicating customers' orders in terms of size, colour and clothing styles is crucial and that follow-ups should be conducted on material shortages with suppliers $(80,3 \%)$. A very high level of agreement $(85,7 \%)$ was also found with regard to the importance of manufacturers informing retail stores about stock shortages or any production problems, as well as the continual reviewing of the product process of the supply of clothes $(82,2 \%)$. The following statements had very high levels of agreement:

- Communicating customers' orders in terms of size, colour $(85,7 \%)$

- Follow-ups on material shortages with suppliers $(80,3 \%)$

- Manufacturers informing retail stores about stock shortages or any production problems $(85,7 \%)$

- Continual reviewing of the product process of the supply of clothes $(82,2 \%)$

Table 1: Description of statements relating to scheduling the manufacturing of customers' orders

\begin{tabular}{ll}
\hline Statement & Description of statement \\
\hline A2.1 & Historical clothing sales information is considered. \\
A2.2 & The development of a team that plans for customer needs is crucial. \\
A2.3 & Continual reviewing of the product process of the supply of clothes is important. \\
A2.4 & Manufacturing processes that are not properly managed will result in continuous rework. \\
A2.5 & $\begin{array}{l}\text { It is important for manufacturers to inform retail stores about stock shortages or any } \\
\text { production problems. }\end{array}$ \\
A2.6 & It is necessary to conduct follow-up on material shortages with suppliers. \\
A2.7 & Manufacturing processes can only be finalised when customers' orders and specifications are \\
A2.8 & confirmed. \\
A2.9 & Fabric orders must be placed before the sales season starts. \\
A2.10 & Retailers' demands regarding low cost charges on orders should be accommodated. \\
A2.11 & Clothing materials or fabrics needed in the manufacturing process may arrive late. \\
A2.12 & Meeting customers' orders on time is affected by the late arrival of clothing materials or \\
A.2.13 & fabrics. \\
A2.14 & Communicating customers' orders in terms of size, colour and clothing styles is crucial.
\end{tabular}

Source: Questionnaire

Planning for fashion clothes: Respondents were asked to indicate their level of agreement on fifteen (15) statements relating to planning for fashion clothes. Figure 2 below shows the percentage of respondents of the clothing industry stakeholders who strongly disagreed or disagreed, who neither agreed nor disagreed and who agreed or strongly agreed with the statements regarding planning for fashion clothes. Table 2 presents the description of the statement numbers in Figure 2. 
Figure 2: Perception of the respondents regarding planning for fashion clothes (as a \%)

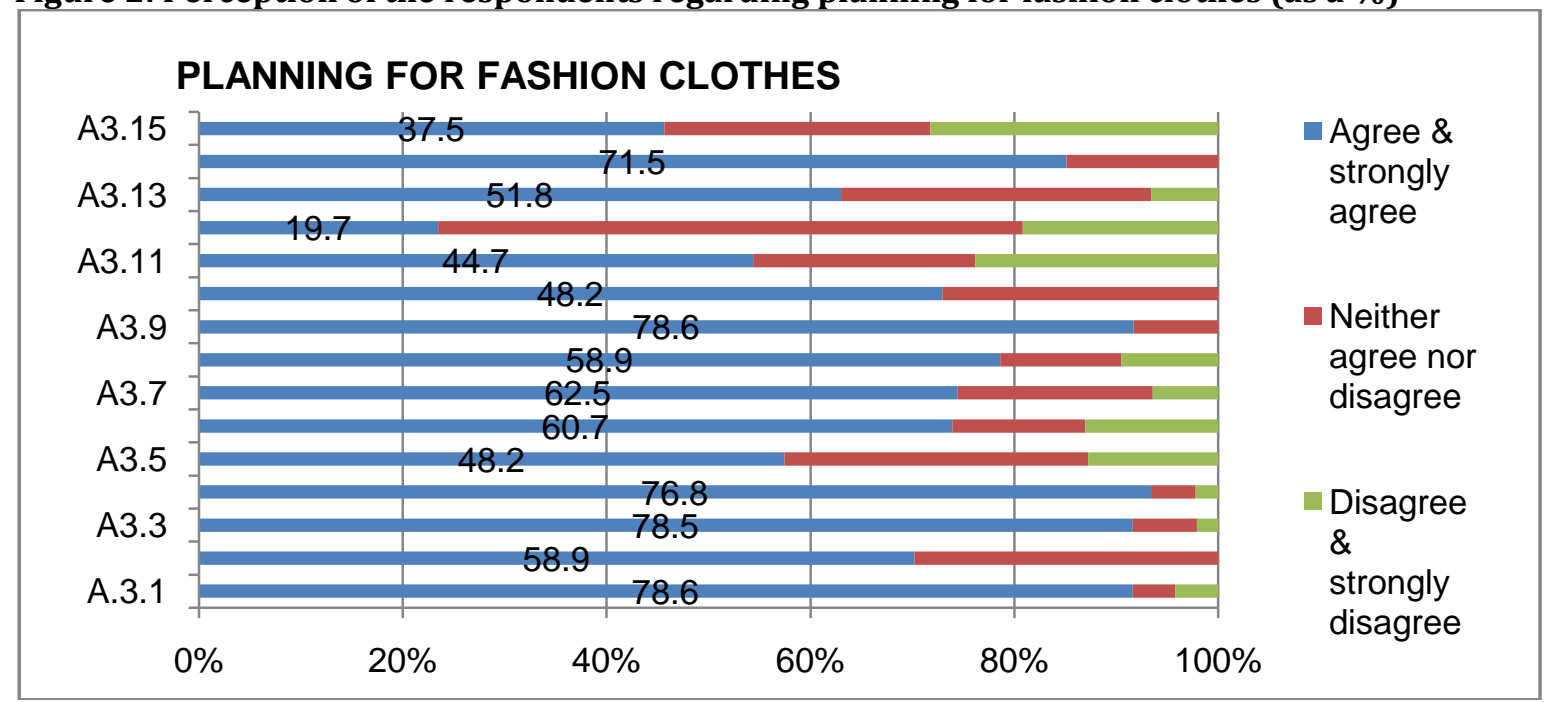

Table 2: Description of the statements relating to planning for fashion clothes

\begin{tabular}{|c|c|}
\hline Statement & Description of statements \\
\hline A3.1 & $\begin{array}{l}\text { Customers' changing needs regarding fashion clothes should be considered when } \\
\text { planning and estimating future clothing needs. }\end{array}$ \\
\hline A3.2 & $\begin{array}{l}\text { The expertise of estimators in manufacturing should be considered when planning } \\
\text { and estimating future customer needs. }\end{array}$ \\
\hline A3.3 & Ionitoring fashion movements is important. \\
\hline A3.4 & $\begin{array}{l}\text { listorical sales information should be updated continuously for timely and } \\
\text { ccurate planning. }\end{array}$ \\
\hline A3.5 & is not easy to plan for fashion clothes, because their lifespan is short. \\
\hline A3.6 & is \\
\hline A3.7 & is important to have short manufacturing plans for fashion clothes. \\
\hline A3.8 & sic clothes. \\
\hline A3.9 & iving manufacturers who think upfront and react to market char \\
\hline A3.10 & $\begin{array}{l}\text { ecognising fashion trends has never been easy due to multiple styling levels being } \\
\text { vailable. }\end{array}$ \\
\hline A3.11 & is not easy to plan for fashion clothes due to constant changes in fashion. \\
\hline A3.12 & shion styles may change $8-10$ times a year. \\
\hline A3.13 & $\begin{array}{l}\text { Manufacturers take lots of pressure from retail stores demanding more fashion } \\
\text { variety. }\end{array}$ \\
\hline A3.14 & Tracking and recording of customer changes regarding clothing needs are crucial. \\
\hline A3.15 & It is not easy to keep track of fashion trends due to constant changes in fashion. \\
\hline
\end{tabular}

Source: Questionnaire

The level of agreement varied with 10 of the statements where respondents indicated agreement of more than $50 \%$. Statements with a low level of agreement were:

- It is not easy to plan for fashion clothes due to constant changes in fashion $(44,7 \%)$.

- Fashion styles may change 8-10 times a year $(19,7 \%)$.

- It is not easy to keep track of fashion trends due to constant changes in fashion $(37,5 \%)$.

- Recognising fashion trends has never been easy due to multiple styling levels available $(48,2 \%)$.

- It is not easy to plan for fashion clothes because their lifespan is short $(48,2 \%)$.

The following statements had very high levels of agreement: 
- Customers' changing needs regarding fashion clothes should be considered when planning and estimating future clothing needs $(78,6 \%)$.

- Having manufacturers who think upfront and react to market changes is crucial $(78,6 \%)$.

- Monitoring fashion movements is important $(78,5 \%)$.

- Historical sales information should be updated continuously for timely and accurate planning $(76,8 \%)$.

- Tracking and recording customer changes regarding clothing needs are crucial $(71,5 \%)$.

The point of sale (POS) system usage: Respondents were asked to indicate their level of agreement on eleven (11) statements relating to the POS system. Figure 3 below shows the percentage of respondents of the clothing industry stakeholders who strongly disagreed or disagreed, who neither agreed nor disagreed and who agreed or strongly agreed with statements on the POS system usage. Table 3 presents the description of statements in Figure 3.

In terms of the perception of the respondents on the POS system in Figure 4.6, on average half (50\%) of the respondents were in agreement with seven of the 11 statements relating to the usage of the POS system. These statements were:

- Having a system that communicates clothing information among participants in the clothing industry faster is crucial $(57,2 \%)$.

- Incorrect sales information captured in the POS system will result in incorrect manufacturing plans $(53,5 \%)$.

- A clothing manufacturer should store historical sales information of clothes on the mainframe computer $(53,7)$.

- Manufacturers can use data on the POS system of retail stores to plan future clothing needs $(51,8 \%)$.

- The POS system information of retail/customers provides a history about clothing sales $(57,1 \%)$.

- Access to the POS system information of retail stores/customers is crucial for manufacturers (50\%).

The importance of sharing sales information among suppliers, manufacturers and the end user customers $(48,2 \%)$.

Figure 3: Perception of the respondents regarding the point of sale (POS) system (as a \%)

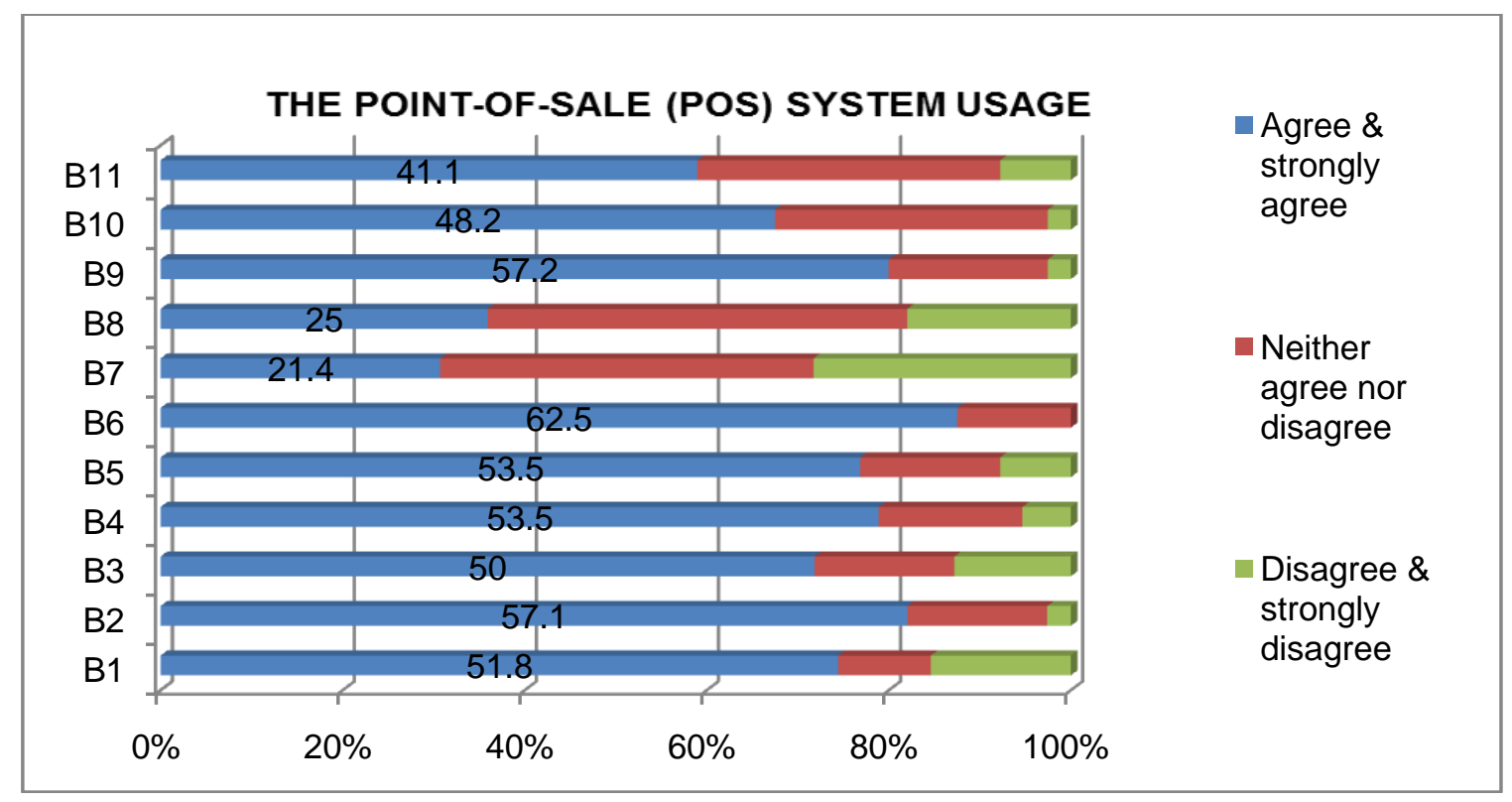


Table 3: Description of statements in Figure 4.6 relating to the point of sale (POS) system

\begin{tabular}{|c|c|}
\hline Statements & Description of statements \\
\hline B1 & $\begin{array}{l}\text { Manufacturers can use data on the POS system of retail stores to plan future } \\
\text { clothing needs. }\end{array}$ \\
\hline B2 & $\begin{array}{l}\text { The POS system information of retail/customers provides history about clothing } \\
\text { sales. }\end{array}$ \\
\hline B3 & $\begin{array}{l}\text { Access to the POS system information of retail stores/customers is crucial for } \\
\text { manufacturers. }\end{array}$ \\
\hline B4 & $\begin{array}{l}\text { Incorrect sales information captured in the POS system will result in incorrect } \\
\text { manufacturing plans. }\end{array}$ \\
\hline B5 & $\begin{array}{l}\text { A clothing manufacturer should store historical sales information of clothes on } \\
\text { the mainframe computer. }\end{array}$ \\
\hline B6 & Storing garment details according to size, colour and design is crucial. \\
\hline B7 & $\begin{array}{l}\text { Historical sales information used by manufacturers to plan future clothing needs } \\
\text { can be purchased from marketing or advertising firms. }\end{array}$ \\
\hline B8 & $\begin{array}{l}\text { Manufacturing factories can send company representatives to gather or collect } \\
\text { historical sales information from retail stores manually. }\end{array}$ \\
\hline B9 & $\begin{array}{l}\text { Having a system that communicates clothing information among participants in } \\
\text { the clothing industry faster is crucial. }\end{array}$ \\
\hline B10 & $\begin{array}{l}\text { The sharing of sales information among suppliers, manufacturers and the end } \\
\text { user customers is crucial. }\end{array}$ \\
\hline B11 & $\begin{array}{l}\text { Test the accuracy of historical sales information on a monthly basis before } \\
\text { planning for future clothing production begins. }\end{array}$ \\
\hline
\end{tabular}

Source: Questionnaire

Storing garment details according to size, colour and design is crucial, and this statement had a slightly higher level of agreement $(62,5 \%)$. A low level of agreement was found for testing the accuracy of historical sales information on a monthly basis before planning for future clothing production begins $(41,1 \%)$. An alarming response (over 70\%) of the clothing industry stakeholders revealed a neutral reaction or disagreement with regard to the following statements:

- Historical sales information used by manufacturers to plan future clothing needs can be purchased from marketing or advertising firms (only $21,4 \%$ agreement).

- Manufacturing factories can send company representatives to gather or collect historical sales information from retail stores manually (only $25 \%$ agreement).

Imports of clothes: When it comes to the imports of clothes, respondents were asked to indicate their level of agreement on twelve (12) statements relating to clothing imports. Figure 4 below shows the percentage of respondents who strongly disagreed or disagreed, who neither agreed nor disagreed and who agreed or strongly agreed with the statements on the importing of clothes. Table 4 presents the description of statements in Figure 4. 
Figure 4: Perception of the respondents regarding the imports of clothes (as a \%)

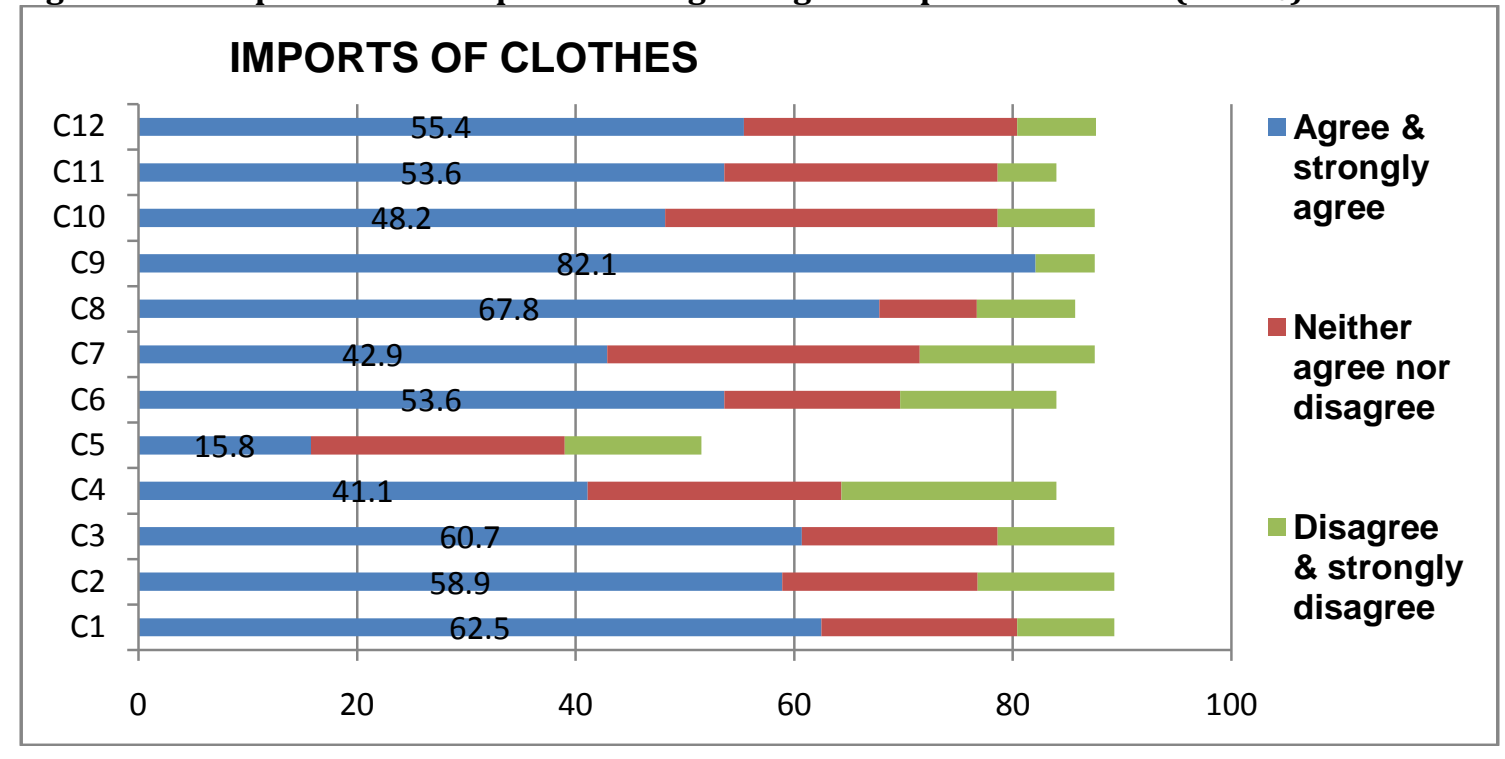

Table 4: Description of statements regarding the imports of clothes

\begin{tabular}{ll}
\hline Statements & Description of statements \\
\hline C1 & $\begin{array}{l}\text { The influx of illegal and legal imports into South Africa results in inaccurate planning in } \\
\text { manufacturing processes. } \\
\text { C2 }\end{array}$ \\
The implementation of low tariff agreements on import rates by the South African \\
government has contributed to an oversupply of clothes in the country. \\
Ch & $\begin{array}{l}\text { Chinese imports contribute to an oversupply of clothes in the clothing manufacturing firms. } \\
\text { Clothing retail stores in South Africa. }\end{array}$ \\
C5 & The oversupply of clothes has resulted in high levels of unsold stock for manufacturers and \\
wholesalers and in retail stores. & \\
C6 & There is a lack of demand for SA clothes because of a high number of clothing imports from \\
C7 & Manufacturing processes need to be reduced to avoid the piling up of clothes in \\
C8 & manufacturing factories. \\
C9 & There is a need for government subsidies in the SA clothing manufacturing industry. \\
C10 & manufacturers. \\
C11 & Currently, the SA government is not financing the clothing manufacturing industry. \\
C12 & There is a lack of capital equipment in SA clothing manufacturing industries. \\
Currently, SA retailers are not supporting local clothing manufacturers.
\end{tabular}

Source: Questionnaire

The statement with the highest level of agreement was that regarding the need for SA clothing retailers and wholesalers to support local clothing manufacturers $(82,1 \%)$. In addition, the majority $(67,8 \%)$ of the clothing industry stakeholders were in agreement that the SA government should support local clothing manufacturers by subsidising the clothing manufacturing industry. However, less than half of the respondents $(48,2 \%)$ were in agreement that the SA government is currently not financing the clothing manufacturing industry, while only $(41,1 \%)$ of the clothing industry stakeholders were in agreement that manufacturing firms do not have enough resources to supply large volumes of orders to the clothing retail stores. In addition, only $42,9 \%$ were in agreement that manufacturing processes need to be reduced to avoid the piling up of clothes in manufacturing factories. In terms of the influx of clothing imports, more than half of the respondents were in agreement about the following: 
- The influx of illegal and legal imports into South Africa results in inaccurate planning in manufacturing processes $(62,5 \%)$.

- The implementation of low tariff agreements on import rates by the SA government has contributed to an oversupply of clothes in the country $(58,9 \%)$.

- Chinese imports contribute to the oversupply of clothes in the clothing manufacturing industry $(60,7 \%)$.

- There is a lack of demand for SA clothes because of the high number of clothing imports from China $(53,6 \%)$.

In addition, the responses of the clothing industry stakeholders on the above statements relating to the influx of clothing imports match the arguments indicated in the study literature (Chapter 2) pertaining to the influx of clothing imports.

Estimating future clothing requirements: The estimation of future clothing requirements was one of the factors that were perceived to have an effect on demand planning. Respondents were asked to indicate their level of agreement on ten (10) statements relating the estimating of future clothing requirements ranging from 1 = strongly agree to 5 = strongly disagree. Figure 4.8 below shows the percentage of respondents who strongly disagreed or disagreed, neither agreed nor disagreed and who agreed or strongly agreed with the clothing industry stakeholders regarding estimating future clothing requirements. Table 5 presents the description of statements in Figure 5.

Figure 5: Perception of the respondents regarding estimating future clothing requirements (as a \%)

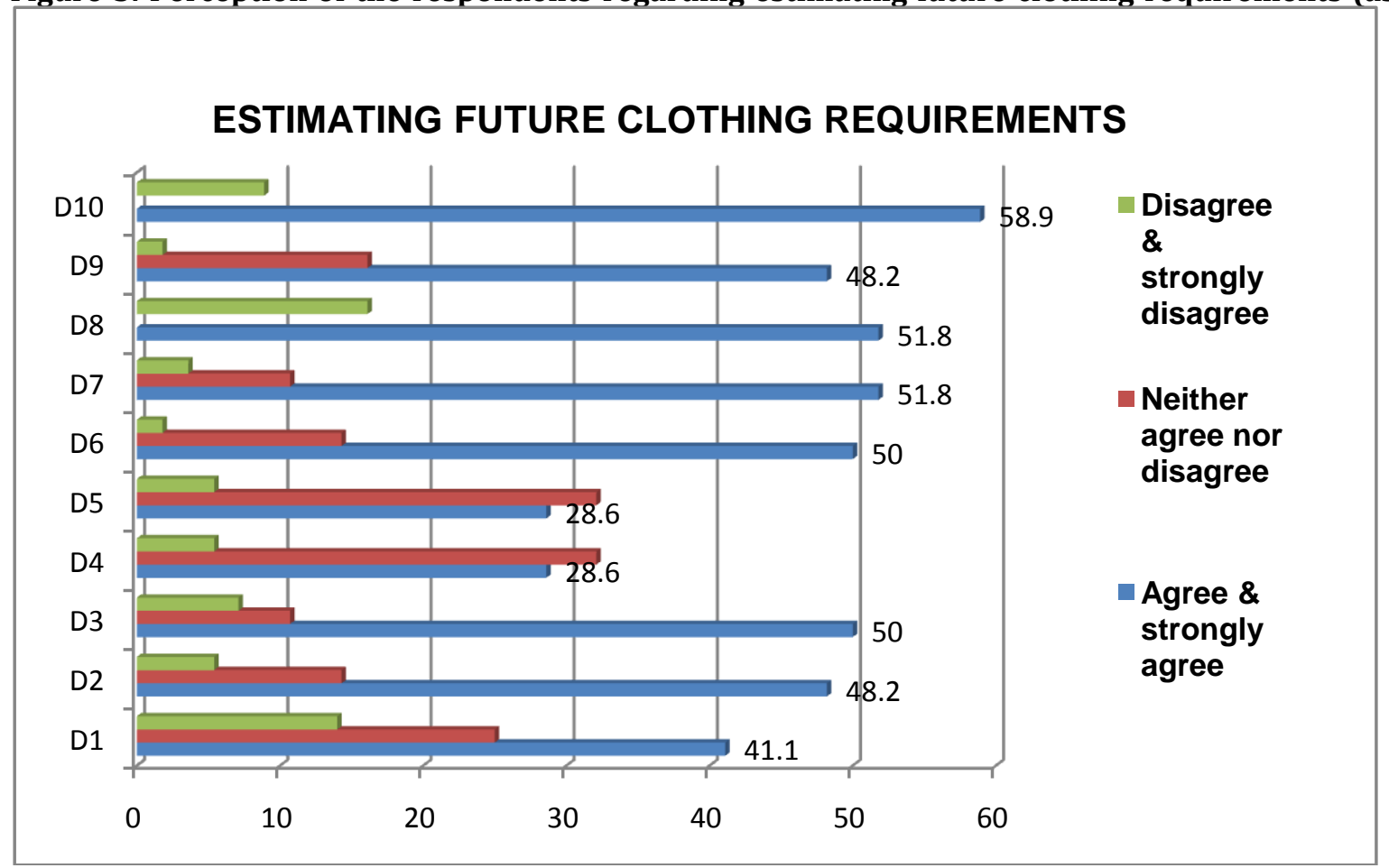


Table 5: Description of statements regarding estimating future clothing requirements

\begin{tabular}{ll}
\hline Statements & Description of statements \\
\hline D1 & The implementing of different methods of estimation for basic and fashion clothing styles is \\
D2 & required. \\
D3 & Esttendance of international trade exhibitions in order to plan ahead for the season. \\
D4 & The tool used for estimating future clothing needs can lose track of clothing sales \\
& information. \\
D5 & Fashion clothes change constantly, which results in errors when estimating trends. \\
D6 & Basic clothes are stable and result in low variances when predicting the future demand. \\
D7 & Manufacturers should conduct estimations of future customer needs according to the \\
& Variance that exists regarding future clothing estimations should be investigated. \\
D8 & Manufacturers should conduct estimations of future customer needs on each clothing style. \\
D9 & Balancing the demand and supply of clothes is crucial to avoid high or low estimations. \\
D10 &
\end{tabular}

Source: Questionnaire

Figure 5 indicates that, on average, half (50\%) of the respondents were in agreement with seven (7) of the ten (10) steps listed on the estimation of future clothing requirements. The highest level of agreement (58,9\%) was on the statement relating to the importance of balancing the demand and supply of clothes to avoid high or low estimations. Furthermore, 51,8\% were in agreement, which means that basic clothes are stable and result in low variances when estimating clothes, and with the statement indicating that manufacturing firms should conduct estimations on future customer needs according to the number of sizes sold previously (51,8\%). In addition, clothing estimators should undergo formal training to improve their skills. Surprisingly, only $28,2 \%$ of the clothing industry stakeholders were in agreement that fashion clothes change constantly and result in errors when estimating trends, and that the tool used for estimating future clothing needs can lose track of clothing sales information.

Recession as an unfavourable economic condition: Respondents were asked to indicate their level of agreement on six (6) statements relating to recession. Figure 6 below shows the percentage of respondents who strongly disagreed or disagreed, who neither agreed nor disagreed and who agreed or strongly agreed with the clothing industry stakeholders regarding the recession as an unfavourable economic condition. Table 6 presents the description of the statements in Figure 6.

Figure 6: Perception of the respondents regarding recession (as a \%)

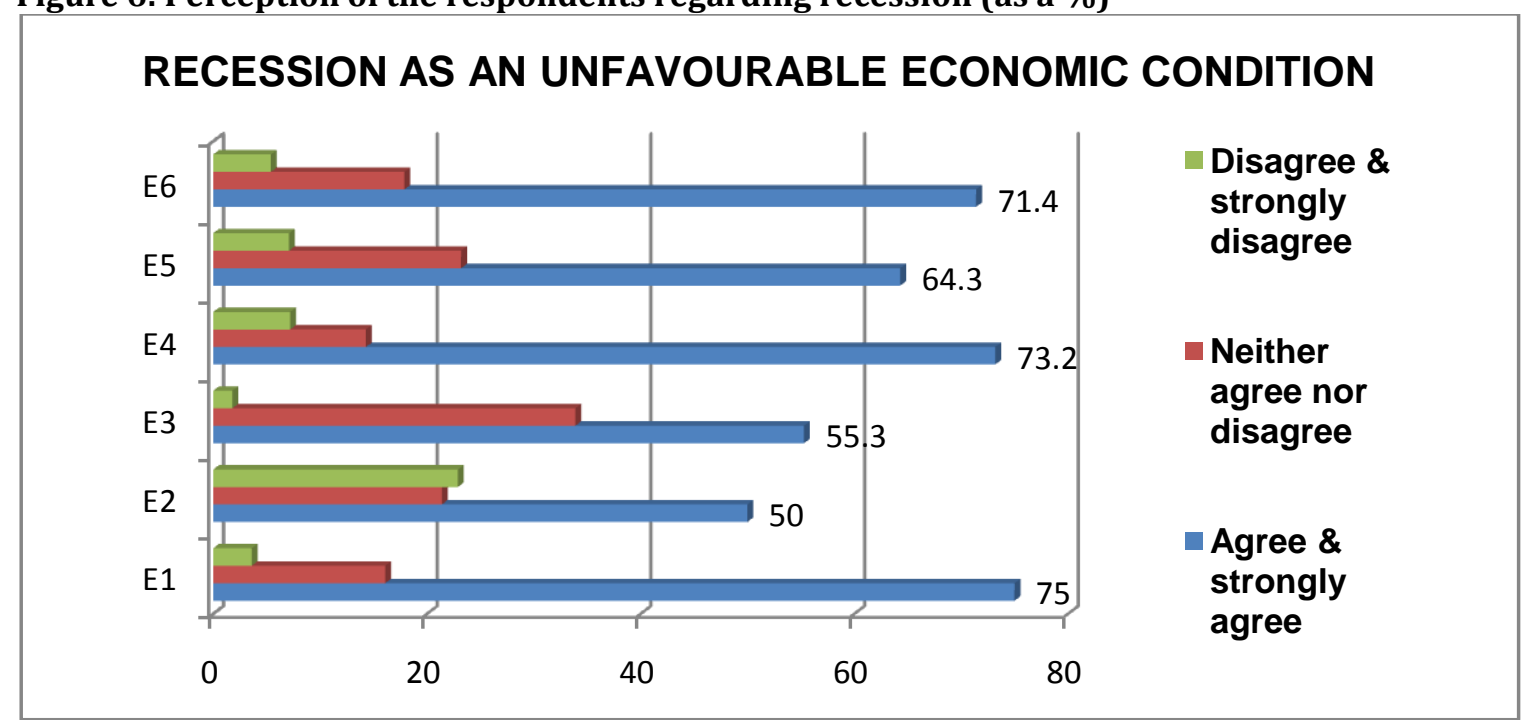


Table 6: Description of statements in Figure 4.9 regarding recession

\begin{tabular}{|c|c|}
\hline Statements & Description of statements \\
\hline E1 & When the SA economy is stable, clothes will sell in large numbers. \\
\hline E2 & $\begin{array}{l}\text { The use of historical clothing sales data does not assist in estimating accurate } \\
\text { future clothing needs. }\end{array}$ \\
\hline E3 & $\begin{array}{l}\text { Before a recession, the use of historical sales data contributes to the level of } \\
\text { accuracy when estimating future clothing needs. }\end{array}$ \\
\hline E4 & $\begin{array}{l}\text { The purchase of non-essential items, such as clothing, fell as a result of the } \\
\text { recession. }\end{array}$ \\
\hline E5 & $\begin{array}{l}\text { During the period of a recession, it is crucial to reduce future customers' orders } \\
\text { as customers' needs decline. }\end{array}$ \\
\hline E6 & $\begin{array}{l}\text { During the period of a recession, it is crucial to manufacture clothes in small } \\
\text { batches. }\end{array}$ \\
\hline
\end{tabular}

Source: Questionnaire

Figure 6 reflects that the majority (over 70\%) of the clothing industry respondents were in agreement (agreed or strongly agreed) with three of the statements relating to the recession. The highest levels of agreement were on the following statements:

- When the SA economy is stable, clothes will sell in large numbers (75\%).

- The purchase of non-essential items, such as clothing, fell as a result of the recession $(73,2 \%)$.

- During the period of a recession, it is crucial to manufacture clothes in small batches $(71,4 \%)$.

For the other three statements, half or more than half of the respondents were in agreement as shown below:

- During the period of a recession, it is crucial to reduce future customers' orders as customers' needs decline $(64,3 \%)$.

- Before a recession, the use of historical sales data contributes to the level of accuracy when estimating future clothing needs $(55,3 \%)$.

- The use of historical clothing sales data does not assist in estimating accurate future clothing needs $(50 \%)$.

The effect of the late arrival of clothes: Respondents were asked to indicate their level of agreement on twelve (12) statements relating to the effect of the late arrival of clothes. Figure 7 below shows the percentage of respondents who strongly disagreed or disagreed, neither agreed nor disagreed and who agreed or strongly agreed with the clothing industry stakeholders regarding the effect of the late arrival of clothes. Table 7 presents the description of the statements in Figure 7.

Figure 7: Perception of the respondents regarding the impact of the late arrival of clothes (in \%)

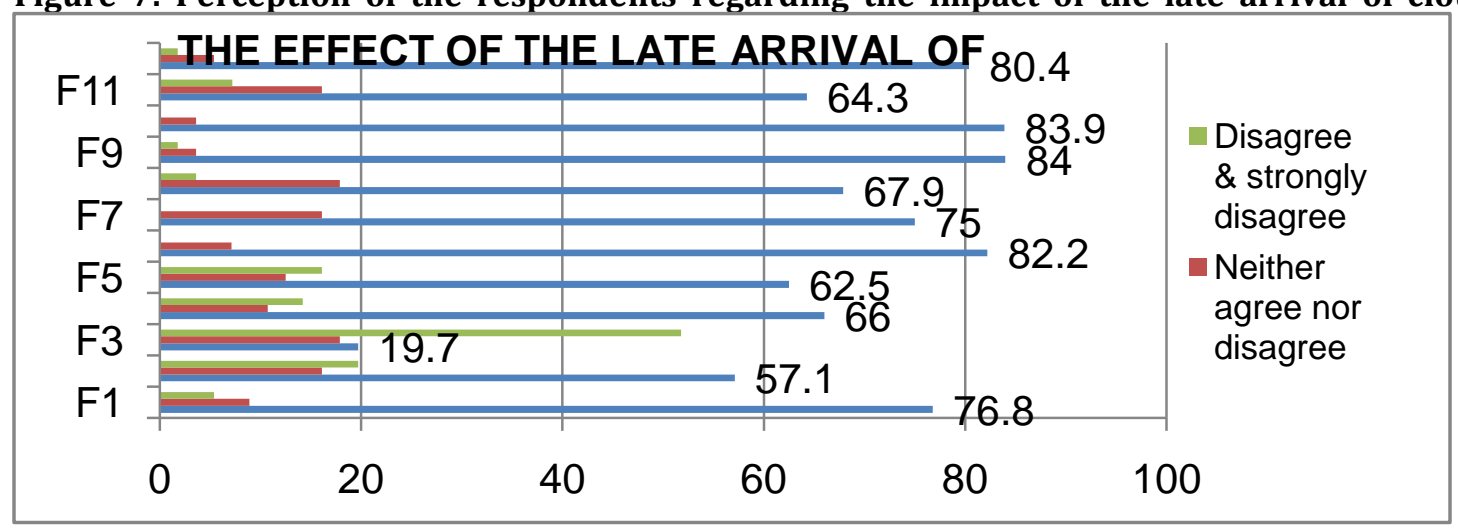


Table 7: Description of statements on the effect of the late arrival of clothes

\begin{tabular}{ll}
\hline Statements & Description of statements \\
\hline F1 & $\begin{array}{l}\text { Manufacturers should order fabrics from both local and international suppliers. } \\
\text { It is not possible to have control over the timely arrival of fabrics. }\end{array}$ \\
F3 & $\begin{array}{l}\text { Fabrics and clothing material used in clothing manufacturing can only be purchased } \\
\text { overseas. }\end{array}$ \\
F4 & $\begin{array}{l}\text { Fabrics and clothing material used in clothing manufacturing can be purchased from } \\
\text { local suppliers. }\end{array}$ \\
F5 & $\begin{array}{l}\text { Orders placed with overseas suppliers may arrive too late for manufacturing. } \\
\text { Late arrival of clothing materials or fabrics should be considered when estimating }\end{array}$ \\
F6. & $\begin{array}{l}\text { future clothing needs. } \\
\text { The timely arrival of clothing material or fabrics may reduce the level of errors when }\end{array}$ \\
F7 & $\begin{array}{l}\text { ostimations regarding future customer needs are implemented. } \\
\text { F8 }\end{array}$ \\
manufacturer in advance.
\end{tabular}

As indicated in Figure 4.8, the majority (over 57\%) of the respondents were in agreement with eleven (11) of the twelve (12) statements relating to the effect of the late arrival of clothes, as listed below:

- Manufacturers should order fabrics from both local and international suppliers $(76,6 \%)$.

- It is not possible to have control over the timely arrival of fabrics $(51,7 \%)$.

- Fabrics and clothing material used in clothing manufacturing can be purchased from local suppliers $(66 \%)$.

- Orders placed with overseas suppliers may arrive late for manufacturing $(62,5 \%)$.

- Late arrival of clothing materials or fabrics should be considered when estimating future clothing needs $(82,2 \%)$.

- The timely arrival of clothing material or fabrics may reduce the level of errors when estimations regarding future customer needs are implemented (75\%).

- Operating within tight schedules and waiting periods will assist manufacturers in the manufacturing process $(67,9 \%)$.

- On-time deliveries assist in ensuring quick manufacturing processes (84\%).

- On-time agreements should be made with suppliers of fabrics to reduce the late arrival of fabrics $(83,3 \%)$.

- Clothing material or fabric orders may arrive when the sales season has already started $(64,3 \%)$.

- Ordering fabrics before the sales season starts is crucial to avoid lost sales on clothing garments $(80,4 \%)$.

It is important to note that the clothing industry stakeholders were in strong disagreement with only one of the twelve (12) statements that were tested in Figure 4.10. The clothing industry stakeholders were neutral or in disagreement with the statement regarding fabrics and clothing material used in clothing manufacturing that can only be purchased overseas $(19,7 \%)$.

\section{Conclusion}

The clothing industry has also experienced a decline in the number of clothing organisations, a decline in the manufacturing output, as well as fluctuating employment. This article explored factors affecting demand planning in the clothing industry in Gauteng, South Africa. An exploratory and descriptive research design, based on the convenience sampling technique, was conducted among clothing industry stakeholders in Gauteng. From a theoretical point of view, the article discusses some of the factors affecting demand planning 
in the clothing industry. The factors stem from the incorrect scheduling of clothing material, planning for fashion clothes, the incorrect use of the point of sale (POS) system, an influx of clothing imports, incorrect estimations of clothes, recession as an unfavourable economic condition, and the late arrival of clothing material. The overall findings indicated that the scheduling of the manufacturing of customer orders was perceived as the most important factor to consider when planning for clothing demand. From this finding, it was specified that more than half (above 50\%) of the respondents perceived planning for fashion clothes, clothing imports, the recession and the effect of the late arrival of fabrics as factors that affect demand planning. The findings also highlight that half (above 50\%) of the respondents perceived POS system usage and the estimation of customer clothing requirements as factors that have an effect on demand planning. Scheduling the manufacturing of customer orders was seen as the factor with the most profound influence on demand planning. The findings also specify that the POS system usage and the estimation of customer clothing requirements are factors with the least effect on demand planning.

This study is unique compared to previous studies which focus on individual factors affecting demand planning. The uniqueness of the study looks at different factors which affects demand planning in Gauteng clothing industry, in South Africa. From the research findings, it clear that product history and teamwork are crucial when scheduling customer clothing orders. The respondents indicated that planning for fashion clothes is a challenge due to their short life span as compared to basic clothes the respondents emphasised that clothing manufacturers should be proactive in reacting to market changes. The findings evidently indicates that correct sales information stored on the POS system assists manufacturers to plan for customers' needs. The research findings revealed that clothing manufacturers need to have access to the POS system of retail customers in order to plan for actual clothing demands. The findings also indicated that the influx of clothing imports into South Africa results in inaccurate planning in manufacturing processes. It is clear that during global recession, the purchase of non-essential items, such as clothing, decreases. Hence, the importance of small-batch manufacturing during a period of recession was emphasised greatly in the responses. The respondents agreed with the statements on the effect of the late arrival of clothes. The respondents agreed that on-time deliveries assist in ensuring quick manufacturing. It is suggested the clothing industry of Gauteng in South Africa consider these factors in their demand planning process for accuracy and proper planning to exist processes. It is evident that all these factors may be the reasons for the challenges faced by the clothing industry with regard to demand planning, or that they may contribute to it. It is imperative that clothing industry stakeholders take into considerations these factors when planning for their demand. Through the application of proper demand planning practices, customer needs can be fully met, thus improving the performance of the clothing industry.

\section{References}

Aksoy, A., Ozturk, N. \& Sucky, E. (2012). A decision support system for demand forecasting in the clothing industry. International Journal of Clothing Science and Technology, 24(4), 221-236.

Annadurai, K. \& Uthayakumar, R. (2010). Reducing lost-sales rate in (T, R, L) inventory model with controllable lead time. Applied Mathematical Modelling, 34(11), 3465-3477.

Barnes, L. \& Lea-Greenwood, G. (2010). Fast fashion in the retail store environment. International Journal of Retail \& Distribution Management, 38(10), 760-772.

Bhardwaj, V. \& Fairhurst, A. (2010). Fast fashion: response to changes in the fashion industry. The International Review of Retail, Distribution and Consumer Research, 20(1), 165-173.

Castelli, C. M. \& Brun, A. (2010). Alignment of retail channels in the fashion supply chain: An empirical study of Italian fashion retailers. International Journal of Retail \& Distribution Management, 38(1), 24-44.

Chaudhary, A. (2011). Changing structure of Indian textile industry after MFA (Multi Fiber Agreement) phase out: A global perspective. Far East Journal of Psychology and Business, 2(2), 1-23.

Chaudhry, H. \& Hodge, G. (2012). Postponement and supply chain structure: Case from the textile and apparel industry. Journal of Fashion Marketing and Management, 16(1), 64-80.

De Villiers, G., Nieman, G. \& Niemann, W. (2011). Strategic logistics management: A supply chain management approach. Van Schaik.

Folk, A. B., Bohen, D. C., Sanders, W. T. \& Johnson, S. A. (2011). U.S. Patent No. 7,900,829. Washington, DC: U.S. Patent and Trademark Office. 
Gereffi, G. \& Frederick, S. (2010). The global apparel value chain, trade and the crisis: challenges and opportunities for developing countries. World Bank Policy Research Working Paper Series.

Gereffi, G. \& Lee, J. (2012). Why the world suddenly cares about global supply chains. Journal of Supply Chain Management, 48(3), 24-32.

GGDA (Gauteng Growth and Development Agency). (2014).Business Intelligence. Sector fact sheet: textile, clothing, leather and footwear. Retrieved from http://www.lemmasijura.co.za/ggdasite/index.php/knowledgecentre/publicataions/category/28sector-reports.

Hamister, J. W. (2012). Supply chain management practices in small retailers. International Journal of Retail \& Distribution Management, 40(6), 427-450.

IQ Business. (2014). Clothing, textile, footwear and leather sector: A profile of the clothing, textile, footwear and leather sub-sectors. Fibre Processing \& Manufacturing Sector Education and Training Authority.

Jonson, A. \& Tolstoy, D. (2012). A thematic analysis of research on global sourcing and international purchasing in retail and firms. International Journal of Retail \& Distribution Management, 42(1), 5683.

Karnin, E. D. \& Walach, E. (2015). U.S. Patent No. 8,818,875. Washington, DC: U.S. Patent and Trademark Office.

Kim, K. (2012). Demand analysis of clothing and footwear: The effects of price, total consumption expenditures and economic crisis. Journal of the Korean Society of Clothing and Textiles, 36(12), 12851296.

Larsson, J., Peterson, J. \& Mattila, H. (2012). The knit on demand supply chain. Autex Research Journal, 12(3), 67-75.

Laudal, T. (2010).An attempt to determine the CSR potential of the international clothing business. Journal of Business Ethics, 96(1), 63-77.

Leedy, P. D. \& Ormrod, J. E. (2014). Practical research: Planning and design. Tenth edition. United States of America: Pearson Education.

Maravelias, C. T. (2012). General framework and modelling approach classification for chemical production scheduling. AIChE Journal, 58(6), 1812-1828.

Mason-Jones, R., Naylor, B. \& Towill, D. R. (2000).Lean, agile or leagile? Matching your supply chain to the marketplace. International Journal of Production Research, 38(17), 4061-4070.

Media Club South Africa. (2015). South Africa's economy: Key sectors. Retrieved from: http://www.mediaclubsouthafrica.com/africa/37-economy/economy-bg/111-sa-economy-keysectors.

Nattrass, N. \& Seekings, J. (2012). Differentiation within the South African Clothing Industry: Implications for Wage Setting and Employment. Centre for Social Science Research.

Nenni, M. E., Giustiniano, L. \& Pirolo, L. (2013). Demand forecasting in the fashion industry: a review. International Journal of Engineering Business Management, 5(37), 1-6.

Ni, Y. \& Fan, F. (2011). A two-stage dynamic sales forecasting model for the fashion retail. Expert Systems with Applications, 38(3), 1529-1536.

Nordås, H. K. (2004). The global textile and clothing industry post the agreement on textiles and clothing. World, 7(1,000).

Oberhofer, M. A. (2012). Fashioning African Cities: The Case of Johannesburg, Lagos and Douala. Streetnotes, 20(01), 65-89.

Powell, D. \& Steytler, N. (2010).The impact of the global financial crisis on decentralized government in South Africa. In Federalism and the Global Financial Crisis: Impacts and Responses' conference, Philadelphia, PA and Rutgers University, Camden, NJ.

Priem, R. L. \& Swink, M. (2012).A demand-side perspective on supply chain management. Journal of Supply Chain Management, 48(2), 7-13.

Priest, A. (2005). Uniformity and differentiation in fashion. International Journal of Clothing Science and Technology, 17(3/4), 253-263.

Ramdass, M. K. (2007). An engineering management framework for the SA clothing industry with a focus on Kwa-Zulu Natal (Doctoral dissertation, University of Johannesburg).

Rexhausen, D., Pibernik, R. \& Kaiser, G. (2012). Customer-facing supply chain practices-The impact of demand and distribution management on supply chain success. Journal of Operations Management, $30(4), 269-281$. 
Rotunno, L., Vézina, P. L. \& Wang, Z. (2013). The rise and fall of (Chinese) African apparel exports. Journal of development Economics, 105, 152-163.

SACTWU (South African Clothing and Textile Workers Union). (2012). Manufacturing address list for sale.NBC (Northern) FMR064G. Johannesburg: SACTWU.

Salm, A. (2002). South African garment industry subsector study. South Africa: The ComMark Trust.

Schreiber, G. (2013). South African fashion handbook. Cape Town: Schreiber Media.

Sekerden, F. (2011).Status of Textile and Clothing Imports and Exports in Turkey. Fibres \& Textiles in Eastern Europe, 3(86), 7-9.

Şen, A. (2008). The US fashion industry: a supply chain review. International Journal of Production Economics, 114(2), 571-593.

Shen, B., Choi, T. M., Wang, Y. \& Lo, C. K. (2013). The coordination of fashion supply chains with a risk-averse supplier under the markdown money policy. IEEE Transactions on Systems, Man, and Cybernetics: Systems, 43(2), 266-276.

Staritz, C. \& Morris, M. (2013). Local embeddedness, upgrading and skill development: global value chains and foreign direct investment in Lesotho's apparel industry.

Surchi, M. (2011). The temporary store: a new marketing tool for fashion brands. Journal of Fashion Marketing and Management: An International Journal, 15(2), 257-270.

Thomassey, S. (2010). Sales forecasts in clothing industry: The key success factor of the supply chain management. International Journal of Production Economics, 128(2), 470-483.

Vlok, E. (2006). The future of the textile and clothing industry in sub-Saharan Africa: The Textile and clothing industry in South Africa. Bonn: Friedrich-Ebert-Stiftung, 229, 227-236.

Wang, K., Gou, Q., Sun, J. \& Yue, X. (2012). Coordination of a fashion and textile supply chain with demand variations. Journal of Systems Science and Systems Engineering, 21(4), 461-479.

Wark, M. (2006). Fashion the future: Fashion, clothing, and manufacturing of post-Fordist culture. Cultural Studies, 5(1), 61-76.

Pretorius, G. (2013). Improving planning at L'Oréal South Africa: A case study. Paper presented at the SAPICS 35th Annual Conference and Exhibition, Sun City, 2-4 June.

Wong, W. K. \& Guo, Z. X. (2010). A hybrid intelligent model for medium-term sales forecasting in fashion retail supply chains using extreme learning machine and harmony search algorithm. International Journal of Production Economics, 128(2), 614-624. 